\title{
Groundwater resources in South America
}

\author{
E-mail: aldocr@mandic.com.br
}

Reliance on groundwater has increased greatly in South America over the past 20 years, in part as a response to the growing costs and other constraints in storing and treating surface water and partly because the economic advantages of groundwater use are now better understood. Nevertheless, groundwater withdrawn from aquifers (taken for use) is difficult to estimate because most comes from uncontrolled private and public wells. The vulnerability of groundwater to overuse and water-
Until currently South America seems vast with huge regions virtually untouched by human settlement. Nevertheless, extremely high concentrations occur in 21 large urban centers, whose populations exceed 1 million. Over concentration has reached alarming levels in 4 great metropolitan areas: São Paulo (16 million), Buenos Aires (12 million), Rio de Janeiro (10 million) and Lima with more than 5 million inhabitants (U.N., 1989). As a result, increasingly environmental degradation is blighting the natural resources of the region, decreasing its productive potential for current and future generations, and threatening human health and the very existence of countless plant and animal species. quality degradation was not widely understood until recently. This descriptive review summarizes major hydrogeological conditions, groundwater resources and usage in South America, and comments upon the need for improved knowledge, more skilled professionals, better legislation and sounder management. Yet there is a lack of experience in the management of crossboundary groundwater systems. Moreover, the difference in the nature of groundwater and surface water preclude direct transfer of experience gained in managing cross-boundary rivers and lakes to the management of cross-border groundwater basins. Therefore, everywhere in South America people must begin to realize they can no longer follow the philosophy of use and discard of water. For many urban areas this approach is not merely another alternative, but the only one available.

\section{Introduction}

South America extends over 17.5 million $\mathrm{km}^{2}$ and includes 12 Nations that shall have 367 million people in 2000. Since Columbus' arrival, 500 years ago, the development model has been based on the idea that water and other natural resources were unlimited and the discoverer believed to have the right to extract them widely and to subjugate the native peoples.

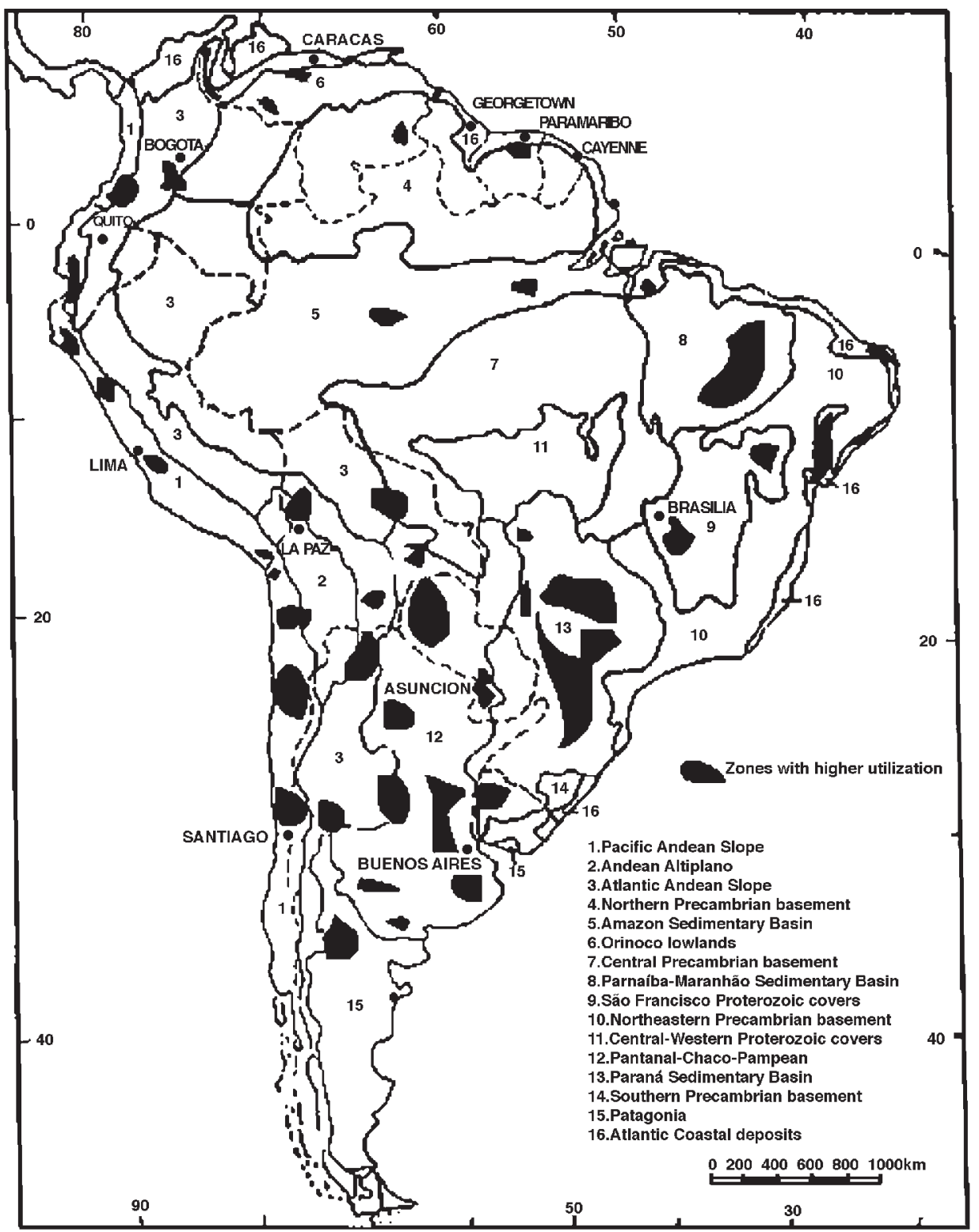

Figure 1 South America - Hydrogeological provinces and zones with higher utilization of groundwater. 


\section{Hydrogeological Provinces}

On the basis of the major geological, tectonic and climate features, sixteen hydrogeological provinces have been distinguished in South America (Figure 1). The preparation of its Hydrogeological Map Scale 1:5000 000 was coordinated by UNESCO and published by the Departamento Nacional da Produção Mineral do Brasil/Cia de Pesquisas de Recursos Minerais-CPRM (1996).

\section{Province 1 - Pacific Andean Slope}

This province covers a long narrow area along the Pacific coast line. A great variety of rocks, from pre-Cambrian to Quaternary are present, and consequently there is a wide range of water-bearing formations. The most productive aquifers are formed by alluvial fans, volcaniclastic materials and by lacustrine deposits. Recharge occurs mainly from river floods that come from the mountains, and in some cases from snow melting, irrigation system percolation, and from water supply and sewage network leakage in urban areas.

Groundwater is generally obtained from dug and drilled wells. Most of these drilled wells are generally $150 \mathrm{~mm}$ or $200 \mathrm{~mm}$ in diameter and around $100 \mathrm{~m}$ deep; only a small proportion is over 200 $\mathrm{m}$ in depth. Well yields generally vary between less than 10 to more than $300 \mathrm{~m}^{3} / \mathrm{h}$, with specific capacities ranging between less than 1 $\mathrm{m}^{3} / \mathrm{h} \cdot \mathrm{m}$ and $10 \mathrm{~m}^{3} / \mathrm{h} \cdot \mathrm{m}$ (Rebouças, 1991).

\section{Province 2 - Andean Altiplano}

This context includes extensive closed drainage basins where water-bearing formations are formed by Tertiary-Quaternary volcanic deposits. Occasionally and locally the aquifers are unconfined, semi-confined or confined, with thickness that may reaches $150 \mathrm{~m}$. Specific capacity of wells vary between $3 \mathrm{~m} 3 / \mathrm{h} \cdot \mathrm{m}$ and $18 \mathrm{~m} / \mathrm{h} \cdot \mathrm{m}$, and quality is generally good for domestic usage and industrial water supply.

Certain areas may be affected by thermal and salt springs. The "Salaris" that occur in this context are, in some order, discharging "playas" supplied by spring systems, with fairly constant discharge, elevated temperatures and high concentrations of dissolved salts (Rebouças, 1991, da Franca \& Mente, 1996).

\section{Province 3 - Atlantic Andean Slope}

This hydrogeological context extends all over the east Andean foothill and includes important water-bearing formations, mainly represented by alluvial fans and pyroclastic materials, fractured volcanic rocks and associated lacustrine deposits. Recharge occurs mainly from precipitation, river floods on alluvial fans. The alluvial fans and foothill associated sediments have thickness of more than $500 \mathrm{~m}$ and constitute the best aquifers used mainly for urban supply (Cochabamba-Bolivia) and for irrigation (Cordoba, Mendoza and Tucuman- Argentina). The aquifer conditions may vary from unconfined to confined or semi-confined and well specific capacities may reach $80 \mathrm{~m}^{3} / \mathrm{h} \cdot \mathrm{m}$ (Rebouças, 1991).

\section{Province 4 - Northern Precambrian basement}

The rock types include gneiss, granite, diorite, quartzite (forming the hills) and schist or similar types in the topographic lowlands. The main water-bearing formations are represented by the deeply weathered basement mantle or regolith and cover deposits. In view of the very scarce hydrogeological information the groundwater use is supposed very low. Dug wells have yielded as much as $5-10 \mathrm{~m}^{3} / \mathrm{h}$ and water quality is characterized by its very low TDS content and pH usually around 4-5 (Rebouças, 1991, da Franca \& Mente, 1996).

\section{Province 5 - Amazon Sedimentary Basin}

Groundwater is increasing in importance in Amazon water supplies, despite the abundance of surface water resources, in part as a response to the growing costs and other constraints in treating surface water and partly because the advantages of groundwater are now better understood. The sedimentary basin covers around 1.3 million $\mathrm{km}^{2}$ and has been filled to $7000 \mathrm{~m}$, largely with Paleozoic and Cenozoic deposits. The former, mostly fine-grained sandstones, crop out in long narrow areas along both the north and the south sides of the lower Amazon Basin; some may yield significant supplies of groundwater.

Most groundwater comes, however, from the Cenozoic waterbearing formations, which covers about 1,5 million $\mathrm{km}^{2}$ at an average thickness of $600 \mathrm{~m}$. Groundwater is generally obtained from drilled wells, which mostly have $150 \mathrm{~mm}$ in diameter and around $100 \mathrm{~m}$ deep; only a small proportion are over $200 \mathrm{~m}$ in depth. In metropolitan areas, such as Manaus, Santarém and Belém, well yields range from $60 \mathrm{~m}^{3} / \mathrm{h}$ to more than $400 \mathrm{~m}^{3} / \mathrm{h}$, with specific capacities ranging from $2 \mathrm{~m}^{3} / \mathrm{h} \cdot \mathrm{m}$ to $20 \mathrm{~m} 3 / \mathrm{h} \cdot \mathrm{m}$ (Rebouças, 1988, Tancredi, 1997). The volume of freshwater stored in the water-bearing formations of the Amazon Sedimentary Basin is estimated at $32500 \mathrm{~km}^{3}$. TDS are less than $100 \mathrm{mg} / \mathrm{l}$, but chemical corrosion can cause severe damage in wells. In fact, groundwater is rich in carbon dioxide $\left(\mathrm{CO}_{2}\right)$, oxygen $\left(\mathrm{O}_{2}\right)$, hydrogen sulfide $\left(\mathrm{H}_{2} \mathrm{~S}\right)$, mainly (Rebouças, 1988, 1991).

\section{Province 6 - Orinoco lowlands}

This province consists of the lowland plains of Colombia and Venezuela. The main water-bearing formations consist of alluvial deposits of Quaternary age. Groundwater is generally extracted from drilled and dug wells. Most of the drilled wells are generally $150 \mathrm{~mm}$ in diameter and around $100 \mathrm{~m}$ deep, but some may reach $300 \mathrm{~m}$ in depth and have yielded more than $500 \mathrm{~m}^{3} / \mathrm{h}$, with a specific capacity of $10 \mathrm{~m} / \mathrm{h} \cdot \mathrm{m}$. Groundwater quality is generally good for domestic usage (Rebouças, 1991; da Franca \& Mente, 1996).

\section{Province 7 - Central Precambrian basement}

Precambrian rock units in this region are covered locally and occasionally by discontinued mantle of Cenozoic deposits or older rock formations. The very scarce hydrogeological data are a result of the low population density ( 2 to 5 inhabitant $/ \mathrm{km}^{2}$ ) combined with the abundance of surface water in rivers and springs - depression springs, contact springs, joint springs or fracture springs. In the most important cities drilled wells are yielding from 5 to $50 \mathrm{~m}^{3} / \mathrm{h}$ and groundwater is used for domestic supply and industries (Rebouças, 1991).

\section{Province 8 - Parnaíba-Maranhão Sedimentary Basin}

Parnaíba-Maranhão Sedimentary Basin, covering around 700 $000 \mathrm{~km}^{2}$ with a maximum thickness of more than $8000 \mathrm{~m}$, is an important source of groundwater in Brazil. Sedimentary units dip gently towards the center of the basin and are cut by local faults and diabase dikes. Among the most important water-bearing formations there are the Serra Grande sandstone of Silurian age (50-700 m), the Devonian Cabeças sandstone (200-300 m), and the Carboniferous Piauí and Poti sandstone (200-300 m). They are separated by prominent shale beds, but also have many sandy beds that yield water, most of that is too salty to be used.

Some thousand wells penetrate the principal aquifers and furnish supplies for domestic, industrial usage and irrigation. Many are less than $100 \mathrm{~m}$ deep, and only a small proportion are deeper than $300 \mathrm{~m}$. Water quality in these Paleozoic rocks depends on its position in respect to the drainage level, which is controlled by the local intermediate or regional groundwater flow systems, rather than on 
the formation that contains it. Usually the water up to $1000 \mathrm{~m}$ below the surface is of good quality, though rather hard for domestic usage and with high sulfate contents for irrigation. The Mesozoic deposits that are exposed in Maranhão state yield water in comparatively moderate quantities, but enough for domestic and for industrial uses as well as for small irrigation schemes.

The volume of freshwater stored in the water-bearing formations of the Parnaiba-Maranhão Sedimentary Basin is estimated at $17500 \mathrm{~km}^{3}$ and existing wells yield as much as 50 to $500 \mathrm{~m}^{3} / \mathrm{h}$. Based on the river base flow data natural recharge has been estimated at around $3.0 \mathrm{~km}^{3}$ per year (Rebouças, 1976, 1988, 1991).

\section{Province 9 - São Francisco Proterozoic covers}

This province is formed by Paleo-Proterozoic covers such as quartzite and meta-conglomerate with fractured aquifer zones and Upper-Proterozoic formations showing karst dissolution in limestone and dolomite. Finally, sandstone Mesozoic Urucuia deposits with thickness over $8000 \mathrm{~m}$ store groundwater in high quantities, enough for irrigation, domestic and industrial uses. Existing well yields vary widely from less than 10 to more than $200 \mathrm{~m}^{3} / \mathrm{h}$, and are used mainly for domestic supply and irrigation. The volume of freshwater groundwater is estimated at $400 \mathrm{~km}^{3}$, and based on river base flow data, the natural recharge has been evaluated at $4.0 \mathrm{~km}^{3}$ per year (Rebouças, 1967, 1988, 1991).

\section{Province 10 - Northeastern Precambrian basement}

This province extends over $600000 \mathrm{~km}^{2}$ in the semiarid region of Northeast Brazil, where fractured rock aquifers can be found in denuded igneous, metamorphic and other significantly deformed Precambrian rocks. The storage capacity of unweathered basement rocks is restricted to interconnected systems of fractures, joints and fissures, which are primarily the result of regional tectonic phenomena.

About 50000 water wells have been drilled during the last decades in this province, but useful information is available in widely scattered files only for less than a third of the wells (Costa, 1986; Manoel Filho, 1996). Since the first systematic scientific research was started, an improvement has been observed in most of the aspects of the well location, construction and groundwater pumping equipment - wind mills and electrical pumps.

Groundwater from fractured rock aquifers commonly has TDS content higher than $2000 \mathrm{mg} / \mathrm{l}$, ranging from 500 to $35000 \mathrm{mg} / \mathrm{l}$. In areas with rainfall values higher than $800 \mathrm{~mm} / \mathrm{y}$, existing wells have mean yield of $10 \mathrm{~m}^{3} / \mathrm{h}$ and groundwater TDS content is generally less than $100 \mathrm{mg} / \mathrm{l}$. Many papers (e.g. Cruz \& Melo, 1968; Rebouças, 1973, 1988; Costa, 1986; Oliveira, 1997) have already focused attention on the importance of these climatic aspects.

Subordinate aspects such as regional tectonic framework (Paleotectonic and Neotectonic) and technical assistance during all phases of well location, design, construction and usage, are the other important factors to be taken into consideration. Based on regional tectonic aspects, five rock systems have been recognized: (1) Cratons and massifs, where specific yields of wells are greater than $1.5 \mathrm{~m} 3 / \mathrm{h} \cdot \mathrm{m}$ with very good quality water. (2) Cratonic areas of Proterozoic Covers, where values of Q/s are generally greater than $0.5 \mathrm{~m} 3 / \mathrm{h} \cdot \mathrm{m}$, commonly in the range of $1-10 \mathrm{~m} / \mathrm{h} \cdot \mathrm{m}$, and sometimes above it. Some special cases of over $50 \mathrm{~m} / \mathrm{h} \cdot \mathrm{m}$ have been recorded in the Chapada Diamantina, Bahia State. (3) Marginal Fold Belts, where in most cases the values obtained for specific yield are over $0.5 \mathrm{~m} / 3 / \mathrm{h} \cdot \mathrm{m}$ and in some local cases up to $20 \mathrm{~m} 3 / \mathrm{h} \cdot \mathrm{m}$ with no quality constraint. (4) Interior Fold Belts, where hydrogeological conditions (lithology and structures) of these belts tend to be unfavorable, besides the groundwater quality problem, due to the high index of aridity in these areas. (5) Shear Belts or "Lineaments", where only fault zones reactivated by Neotectonic events of extensional character are of hydrogeological interest. There are some quite few cases with excellent results, $\mathrm{Q} / \mathrm{s}$ over $5 \mathrm{~m}^{3} / \mathrm{h} \cdot \mathrm{m}$, which is an incentive for further research programs (Brito Neves \& Albuquerque, 1997).
Statistics on drilled wells in crystalline fractured rock aquifers generally show rather low values for specific yields as follows: around $34 \%$ below $0.1 \mathrm{~m}^{3} / \mathrm{h} \cdot \mathrm{m} ; 34 \%$ between 0.1 and $0.5 \mathrm{~m} 3 / \mathrm{h} \cdot \mathrm{m}$; $13 \%$ between 0.5 and $1 \mathrm{~m} / \mathrm{h} \cdot \mathrm{m}$, and around $13 \%$ above $1 \mathrm{~m} / \mathrm{h} \cdot \mathrm{m}$ (Rebouças, 1973; Manoel Filho, 1996). The frequency of occurrence of productive fractures in these crystalline rocks decreases with depth, and the optimal zone is considered to be around $30 \mathrm{~m}$ deep. The suggested limit for economic drilling is $60 \mathrm{~m}$.

\section{Province 11 - Central-Western Proterozoic covers}

This province is formed mostly by paleo-Proterozoic covers. The best aquifers are the residual deposits - Mesozoic sediments such as sandstone, siltstone, and Cenozoic alluvial deposits. Groundwater is generally obtained from dug and drilled wells with yields varying from 2 to $20 \mathrm{~m}^{3} / \mathrm{h}$. These are mostly used for domestic supplies (da Franca \& Mente, 1996).

\section{Province 12 - Pantanal-Chaco- Pampean}

It is formed by a huge tectonic-structural depression filled by sediments, mostly of Quaternary age. The Pantanal Sub-province is located in Brazil and represents a very extensive wet land. Some excellent aquifers are formed by sand layers inserted between clay and silt beds. Existing wells have mean depth of $50 \mathrm{~m}$ and serve practically all the domestic supplies in the region (Rebouças \& Lastroia, 1989).

The Chaco Sub-province is located in the western region of Paraguay, extending into southeastern Bolivia and northeastern Argentina. Existing wells have depths ranging from 60 to $300 \mathrm{~m}$ with average specific capacity of $1.6 \mathrm{~m} 3 / \mathrm{h} \cdot \mathrm{m}$ (da Franca \& Mente, 1996).

The Pampean Sub-province represents the southern extension of the Chaco, located entirely in Argentina territory. Existing wells have specific capacities ranging from less than $1 \mathrm{~m} / \mathrm{h} \cdot \mathrm{m}$ to more than $10 \mathrm{~m} 3 / \mathrm{h} \cdot \mathrm{m}$. TDS values are from $300 \mathrm{mg} / \mathrm{l}$ up to $2000 \mathrm{mg} / \mathrm{l}$ (da Franca \& Mente, 1996).

\section{Province 13 - Paraná Sedimentary Basin}

The Paraná Sedimentary Basin underlies those most developed region of Brazil (around $1000000 \mathrm{~km}^{2}$ ) and extends into eastern Paraguay $\left(100000 \mathrm{~km}^{2}\right)$, northwestern Uruguay $\left(100000 \mathrm{~km}^{2}\right)$ and northeastern Argentina (400 $000 \mathrm{~km}^{2}$ ). The sedimentary sequence (Silurian to Cretaceous) in this intercratonic basin is almost undisturbed, with gentle dips towards the center of the basin. Local faults may have served as channels for the extruding basalt flows (Rebouças, 1976).

Among the most important aquifers of the Paleozoic sediments are the Furnas sandstone of the Devonian, the Aquidauana and Itarare sandy beds of the Lower Permian, the Rio Bonito Formation of the Middle Permian and the Rio do Rasto Formation of the Upper Permian. As a rule, in the central areas of the basin groundwater in aquifers is rather highly mineralized. Paleozoic aquifers are significant only along the eastern, southern and northwestern narrow margins of the Paraná sedimentary basin, where well yields range from 10 to $50 \mathrm{~m}^{3} / \mathrm{h}$ and TDS content varies widely, from less than 100 $\mathrm{mg} / \mathrm{l}$ to more than $2000 \mathrm{mg} / \mathrm{l}$.

More important as a source of water are Triassic-Jurassic and Cretaceous formations of the Paraná Basin. They are separated by an extensively developed and widespread basaltic package. The Triassic-Jurassic deposits form an aquifer of continental dimension: the Botucatu aquifer, also called Guarany aquifer (Rebouças, 1976, 1994; Araújo et al., 1995). This aquifer is confined by the Cretaceous basalt of the Serra Geral Formation and by underlying Permo-Triassic sedimentary rocks of low permeability. It extends over 839000 $\mathrm{km}^{2}$ in Brazil and $355000 \mathrm{~km}^{2}$ in the eastern part of the ChacoParaná Basin: Paraguay $\left(71700 \mathrm{~km}^{2}\right)$, Argentina $\left(225500 \mathrm{~km}^{2}\right)$ and Uruguay $\left(58500 \mathrm{~km}^{2}\right)$. Jurassic eolian sandstone forms everywhere 
the best part of the aquifer, whereas more argillaceous fluviallacustrine Triassic sandstone is notably inferior (Araújo et al., 1995).

A thick basaltic package (up to $1500 \mathrm{~m}$ ) overlies this aquifer, reducing its exposed areas to only 10 percent of its total area. Not surprisingly, in view of the great depths it reaches (almost $2000 \mathrm{~m}$ ) and the thick confining basaltic cover, the water stored in the Guarany aquifer system is relatively hot $\left(50-90^{\circ} \mathrm{C}\right)$. The volume of water stored in these aquifer systems was estimated at $50000 \mathrm{~km}^{3}$, and the natural recharges based on the river base flow data was estimated at $234 \mathrm{~km}^{3}$ per year (Rebouças, 1976).

About $70 \%$ of its confined area have artesian conditions. Some thousand wells deeper than $500 \mathrm{~m}$ that reach the Botucatu or Guarani aquifer have obtained yields of hundreds or even thousands of $\mathrm{m}^{3} / \mathrm{h}$, supplying cities, industries and hydro-thermal installations or SPA. The specific capacity of wells varies from $4 \mathrm{~m} / \mathrm{h} \cdot \mathrm{m}$ to more than 30 $\mathrm{m}^{3} / \mathrm{h} \cdot \mathrm{m}$. TDS contents are generally less than $200 \mathrm{mg} / \mathrm{l}$. The production cost per cubic meter of water from wells $500-1000 \mathrm{~m}$ in depth with yields $300-500 \mathrm{~m}^{3} / \mathrm{h}$ varies from US\$ 0.01 to US\$ 0.08 , representing only $10-20 \%$ of the cost of storing and treating surface sources (Rebouças, 1976, 1994b).

Basalt flows cover about $1000000 \mathrm{~km}^{2}$ of the Paraná sedimentary basin. Groundwater occurs within the inter-flow zones and along cooling joints of the basalt flows. The "intertrap" sediments greatly increase the average porosity of large volumes of the basalt rocks. Some 5000 wells provide yields between $5 \mathrm{~m}^{3} / \mathrm{h}$ and $20 \mathrm{~m}^{3} / \mathrm{h}$ for domestic usage and small industrial plants. Depths of wells are generally in the order of $100 \mathrm{~m}$, and TDS of water is generally less than $300 \mathrm{mg} / \mathrm{l}$, but sometimes may present excessive iron and silica contents (Rebouças, 1978). The Bauru-Cauiá water-bearing formations of the Cretaceous period, which cover some $315000 \mathrm{~km}^{2}$ with average thickness of $100 \mathrm{~m}$, are fairly cemented, and the water is usually of good quality. About 5000 wells (mostly $150 \mathrm{~mm}$ in diameter to depths around $100 \mathrm{~m}$ ) have been drilled over wide areas of the region, mostly in São Paulo State. They provide practically all the domestic supplies and many of the small industrial and public supplies (Rebouças, 1976).

\section{Province 14 - Southern Precambrian basement}

This province is situated in the southeastern Atlantic shoreline that is shared by Brazil and Uruguay. The storage groundwater capacity is restricted to the interconnected systems of fractures, joints and fissures, which are primarily the result of regional tectonic phenomena. The well yields range between 1 and $36 \mathrm{~m}^{3} / \mathrm{h}$ and TDS value of water is generally low, with mean value of $230 \mathrm{mg} / \mathrm{l}$. Groundwater obtained from these aquifer zones are commonly used for domestic supplies, livestock in rural areas, and small irrigation plans (Rebouças, 1976, 1988).

\section{Province 15 - Patagonia}

At the end of the Paleozoic Era great changes took place in the physical geography of South America, affecting the regions in which sediments accumulated. The Paleozoic formations are not very satisfactory with respect to quantity and quality of the water they contain. Among the most important aquifers are the Upper Cretaceous and Oligocene water-bearing sediments, which form the hydrothermal system with thickness up to $1500 \mathrm{~m}$ in Bahia Blanca, where well yields reach up to $400 \mathrm{~m}^{3} / \mathrm{h}$ and are used for domestic supply and industrial purposes. Most groundwater comes from Tertiary-Quaternary deposits with average thickness of $100 \mathrm{~m}$ and TDS content around $320 \mathrm{mg} / \mathrm{l}$. Existing wells yield as much as 20 to $100 \mathrm{~m}^{3} / \mathrm{h}$.

\section{Province 16 - Atlantic Coastal deposits}

In the relatively narrow and discontinuous coastal sedimentary basins, large quantities of groundwater have been developed from sand aquifers, which dip gently and become thicker seawards. The most important aquifers are Cretaceous and Tertiary sandstone. As a rule, Cretaceous aquifers are the most important in the Bahia "grabben" of Reconcavo-Tucano and Jatobá, where the deposits can reach a thickness of over $16,000 \mathrm{~m}$. In the coastal sedimentary basins such as Potiguar-Recife and Alagoas-Sergipe, productive wells may reach $1,000 \mathrm{~m}$ in depth, yielding from 10 to $400 \mathrm{~m}^{3} / \mathrm{h}$ (Rebouças, 1973, 1988)

The Tertiary/Quaternary formations of the coastal region from Colombia to Uruguay consist mainly of sand and clay, which overlie Cretaceous formations or basement rocks. Like the Cretaceous sedimentary deposits, they dip gently seawards and include a number of unconfined or semi-confined aquifers. The water is generally of good quality, but the iron content is sometimes up to $15 \mathrm{mg} / \mathrm{l}$. Some excellent aquifers are found in sand dunes. However, sanitary leakage infiltration and seawater intrusion are the major constraints on groundwater use and development of surficial coastal aquifers. In areas of dense population, the high to extreme pollution vulnerability is another limiting factor. Important cities of Brazil, such as Natal-RN, Recife-Pe, Maceió-Al are supplied almost totally or complementary from coastal aquifers (Costa et al, 1998, Melo, 1995, Cavalcante, 1998).

\section{Groundwater resources and withdrawal}

From a nationwide standpoint, it may be said that there is no water crisis facing any South America Nations. The water sources of greatest significance for supply purposes are river discharges and groundwater up to $200 \mathrm{~m}$ in depth. From an economic point of view, groundwater storage is particularly important because it remains stable over time and is comparatively better protected from domestic, agricultural and industrial pollution sources.

In South America, the total groundwater discharge to river is estimated at $3736 \mathrm{~km}^{3} /$ year. This means that the annual amount of renewable groundwater resources should represent $10200 \mathrm{~m}^{3}$ per capita/year in the year 2000. Thus, the groundwater availability is five times greater than $2000 \mathrm{~m}^{3}$ per capita/year as estimated by UN for a good standard of life and a sustainable economic development.

Surprisingly, although groundwater resources are very important to health and economy in South America, their occurrence is poorly understood and is the subject of many misconceptions. As a result, groundwater resources are still frequently approached as something mystic or metaphysical by the public in general, and even by professionals. Usually, data obtained from different archives and files are heterogeneous, difficult for statistical treatment and sometimes contradictory.

The first use of groundwater as a source of supply in this region dates from pre-Colombian times. Since the early colonial times, hand-dug wells and crude water-lifting devices have marked the exploitation of groundwater. In fact, in almost all the fortresses, monasteries and other colonial buildings, hand-dug wells can still be found. The introduction of well drilling machinery and motor-driven pumps, in the mid of the last century, made possible the recovery of groundwater in large amounts and at increased depths. There are now no technological limitations to reach deeper confined aquifers in South America. Moreover, as electrical network supplies spread out in almost all the countries of the region, the benefits of groundwater development have become increasingly important. Presently, groundwater use for domestic purposes in urban and rural areas has the highest priority, followed by industrial requirements and then irrigation.

Following the privatization trends of water supply services, development of groundwater resources in South America has been increasing in recent years, partly as a response to the growing costs and other constraints in storing and treating surface water and partly because the advantages of groundwater are now better understood. The vast majority of the hydrogeological studies have been desk studies, e.g., comprehensive analysis of existing information on geology, existing wells, hydrology, chemical analysis, administrative and legal constraints. These studies have been used to solve 
local problems of water supply. Reconnaissance, including field investigation and analyses of existing geological maps, inventory of existing wells, pumping tests, estimate of groundwater resources, is available in most countries. However, the development of groundwater resources is concentrated in certain areas of economic or politic interest, or where surface water are under stress, and there are vast areas with scarcity of data or no data (Rebouças, 1991).

Latin nature or culture, being what it is, interest in groundwater and associated problems is usually stimulated only in times of crisis such as those produced by the extreme droughts. These so called "natural" disasters are normally short-term phenomena that frequently generate a public response of similar duration intercepted with periods of massive indifference. In these circumstances it must be recognized that only a serious effort can bridge the gap. Whenever these hidden resources are to assist in the future alleviation of water-supply problems, a more fundamental understanding of its occurrence and functions is necessary, but it is up to governments and their advisers to ensure that the technical and financial resources continue to be made available to make this possible.

In the region, as a whole, groundwater is generally obtained from three types of wells: drilled, dug and driven. The later two predominate for domestic supplies. About half million deeper wells have been drilled in the last 20 years and are currently in use, mostly supplying public water systems, industries and for agricultural concerns. Most of these wells are generally $150 \mathrm{~mm}$ in diameter and around $100 \mathrm{~m}$ deep; only a small proportion is over $200 \mathrm{~m}$ in depth. In the large sedimentary basins in Brazil there are many wells deeper than $500 \mathrm{~m}$, some between $500 \mathrm{~m}$ and $1,000 \mathrm{~m}$ and very few from $1,000 \mathrm{~m}$ to $2,000 \mathrm{~m}$ in depth. These scenarios are based on data presented by several authors during congresses of ABAS - Associação Brasileira de Águas Subterrâneas, ALHSUD - Asociación Latino Americana de Hidrologia Subterránea para el Desarrollo and some National Chapters of the IAH-International Association of Hydrogeologists.

Unfortunately, comprehensive data are not available on the proportion of water withdrawn from groundwater resources. Thus, to illustrate the vital role played by groundwater the main zones with greater utilization are shown in Figure 1 and some specific cases are described.

\section{Argentina}

Groundwater is mainly used for cattle-breeding all over the country, for domestic and industrial supply in metropolitan areas of Buenos Aires, La Plata, Bahia Blanca, and for irrigation mostly in Cordoba, Mendoza and Tucuman.

\section{Bolivia}

Groundwater is mostly used for human consumption and industry and, secondarily for irrigation. The areas of most intensive use are: La Paz, Oruro, Potosi, Cochabamba, Chuquisaca, Tarija, and Santa Cruz de la Sierra.

\section{Brazil}

Groundwater was considered to be a "local" resource in the early phase of its development, serving domestic and rural needs. Expanded use for municipal and industrial purposes has been experienced over the past 25 years or so. Thus, significant attention has been devoted to defining the regional characteristics and appraising the development of major aquifer systems in the 11 hydrogeological provinces. National or regional hydrogeological maps are available, mainly in Argentina, in the Northeastern and Southeastern region of Brazil, in Venezuela and Chile. Currently, between $70-80 \%$ of the municipal water supply services and $95 \%$ of industries in the State of São Paulo take groundwater for use. About 250000 deep wells have been drilled in Brazil during the last 30 years by municipalities and industry. In almost all the largest metropolitan areas of Brazil (population from 1 million to 16 million inhabitants), such as Manaus,
Belém, São Luis, Recife, Salvador, São Paulo and Curitiba, despite the benefits of surface water supply services, thousands of uncontrolled private wells provide significant groundwater for hotels, hospitals, residential buildings, and industries. This contributes substantially to reduce monthly public water bills and the problems generated by frequent water shortages (Rebouças, 1988). These efforts have yielded a great deal of valuable information to guide management of the Nation's groundwater resources.

\section{Chile}

The main zones with great groundwater withdrawal are in the river basins of Aconcagua, Alqui, Copiapó, Maipo and the metropolitan area of Santiago. In these areas groundwater is mainly used for domestic and industrial purposes, and secondarily for irrigation.

\section{Colombia}

Groundwater is being more intensively used, such as in the Cauca valley for sugar-cane irrigation, in the Savannah of Bogota for flower crops, industrial purposes, breweries, and gaseous water factories. In the northern Colombia, which is subject to droughts, groundwater is basically used for domestic supply, livestock in rural areas, and small irrigation schemes.

\section{Ecuador}

Groundwater is used primarily for domestic supply, and secondarily for industrial purposes and irrigation. In sixteen cities groundwater is of considerable importance, particularly for domestic use.

\section{Paraguay}

Groundwater is mainly used for domestic supply and industrial purposes in the metropolitan area of Asuncion. The regions with the best groundwater resources are the Chaco Alto, Patiño, Misione, and Caacupè. In the Chaco western extension, brackish groundwater has been found in three different situations: (1) areas with surface salt water bodies overlying fresh groundwater aquifer beds; (2) areas with significant amount of shallow fresh groundwater overlying deeper salt groundwater; and (3) areas without significant amount of fresh groundwater.

\section{Peru}

Groundwater is used mainly in the coastal arid zone for domestic supply and irrigation. In the metropolitan area of Lima (5.5 million inhabitants) some 320 production wells provide around one million cubic meters of freshwater per day or $80 \%$ of the total water volume taken for use. Some other twelve urban areas, such as Ciudad Trujillo, Piura, Arequipa, are supplied by drilled wells to depths from 30 to $65 \mathrm{~m}$, yielding 70 to $198 \mathrm{~m}^{3} / \mathrm{h}$. They serve practically all the domestic needs and many of the industrial and irrigation demands.

\section{Uruguay}

Groundwater is increasing in importance in Uruguay water supplies, as a response to the growing costs and other constraints in storing and treating surface water. Currently, in the Montevideo metropolitan area (1.6 million inhabitants) hundreds of wells provide groundwater for around $20 \%$ of the population. However, most of the inhabitants of the rural areas and around $80 \%$ of the urban dwellers of Uruguay use groundwater. The continued expansion in the use of groundwater, mostly in the areas of Tacuarembo aquifer, Ragon aquifer and Mercedes aquifer, results in an ever-increasing need for skilled professionals in the field of resource evaluation, well technology, water use and protection. 


\section{Venezuela}

Groundwater development in Venezuela is significant, mostly in the Maracaibo plain, Quibor region, basin of Valencia and Quanipa terraces, where it is considered to be of great importance for municipal, industrial and irrigation purposes. Groundwater is generally obtained from drilled wells. Most of the wells are generally between 150 and $200 \mathrm{~mm}$ in diameter and 50 to $100 \mathrm{~m}$ in depth, yielding $50 \mathrm{~m}^{3} / \mathrm{h}$ to $150 \mathrm{~m}^{3} / \mathrm{h}$ and more. Groundwater quality tends to be good - TDS values ranging from $100 \mathrm{mg} / \mathrm{l}$ to $700 \mathrm{mg} / \mathrm{l}$.

\section{Conclusions}

Groundwater in Latin America is unevenly distributed in quantity, but the quality is usually good for domestic and industrial supply. As a result, groundwater is an important economic resource in many areas and has been highly committed in several locations, mainly in most populated areas for domestic and industrial purposes. The economic importance of integrated surface and groundwater management is widely recognized, and there is a need now for governments to develop specific strategies for efficient use of groundwater resources. For these purposes, using legislation, regulations and instruments in force, national governments in collaboration with regional and local administrations should initiate reforms to promote a comprehensive framework for groundwater management.

What is urgently needed is the formulation of long-term development policies. This means that its quantity and quality should be maintained at an economically, socially and environmentally optimal level, taking into account the long-term uncertainties and the real long-term costs of controls on its use, protection and rehabilitation. However, the exploitation of groundwater resources in South America poses three sets of challenge: problems of knowledge, problems related to legislation to provide compatible development and conservation strategies, and problems related to the everincreasing need for skilled professionals in the field of resource evaluation, well technology, water use and protection.

\section{References}

ABAS - Associação Brasileira de Águas Subterrâneas, Anais Congressos, (Brazilian Groundwater Association, Congress Proceedings): $1^{\circ}$ Congresso, 1980, Recife, 545 p; $2^{\circ}$ Congresso, 1982 , Salvador, 680 p; $3^{\circ}$ Congresso 1984, Fortaleza, $660 \mathrm{p} ; 4^{\circ}$ Congresso, 1986, Brasilia, $650 \mathrm{p} ; 5^{\circ}$ Congresso, 1988, São Paulo, 680 p; $6^{\circ}$ Congresso, 1990, Porto Alegre, 643 p. $7^{\circ}$ Congresso, 1992, Belo Horizonte, 645 p; $8^{\circ}$ Congresso 1994 , Recife, 643 p; $9^{\circ}$ Congresso, 1996, Salvador, 640 p; $10^{\circ}$ Congresso, 1998, São Paulo, CD-ROM 80 trabalhos.

ALHSUD - Asociacón Latino Americana de Hidrologia Subterránea para el Desarrollo, Actas Congresos, (Latin American Groundwater Association for the Development, Congress Proceedings): $1^{\circ}$ Congreso, 1992, Merida, Venezuela, $450 \mathrm{p} ; 2^{\circ}$ Congreso, 1994, Santiago de Chile, $630 \mathrm{p}$; $3^{\circ}$ Congreso, 1996, San Luis de Potosi, Mexico, 680 p; $4^{\circ}$ Congreso, 1998, Montevideo, Uruguay, $1608 \mathrm{p}$

AIH - Asociación Internacional de Hidrogeologos - Argentina, Actas 1o Congreso Nacional de Hidrogeologia - Argentina, 1997, Baia Blanca, 459 p.

UNESCO - IHP/ DNPM/CPRM, 1996, Hydrogeological Map of South America, Scale 1:5,000,000, Exploratory Text, 212 p, Rio de Janeiro.

Araújo, L.M., França, A.B. \& Potter, P.E.M. 1995. Aqüífero gigante do Mercosul no Brasil, Argentina, Paraguai e Uruguai: mapas hidrogeológicos das formaçies Botucatu, Piramboia, Rosário do Sul, Buena Vista, Misiones e Tacuarembó. Curitiba, Petrobras/UFPR, 16p [mapas].

Brito Neves, B.B., Albuquerque, J.P.T., 1997 Tectonics and groundwater research: Proterozoic Borborema Province, a semiarid region of Northeast Brazil. Engineering Geology and the Environment, Marinos, Koukis, Tsiambaos \& Stoumaras (eds), p.1181-1186.

Costa, W.D., 1986. Análise dos fatores que atuam no aqüífero fissural - área piloto dos Estados da Paraíba e R. G. Norte. PhD thesis, Inst. Geociíncias, Universidade de São Paulo, 206 p.
Cruz, W.B. \& Melo, F.AF., 1968. Estudo Geoquímico preliminar das águas subterrâneas do Nordeste do Brasil. Sèrie Hidrogeologia (SUDENE/ Brasil, 1, 9: $147 \mathrm{p}$.

da Franca. R.A .\& Mente, A., 1996. Hydrogelogical Map of South America, Scale 1: 5000000 - Exploratory Text. 212 p, Brasília.

Manoel Filho, J., 1996. Modelo de dimensão fractal para avaliação de parâmetros hidráulicos em meio fissural. Ph.D. thesis. Inst. Geociíncias, Universidade de São Paulo, 197 p.

Melo, J.G., 1995. Impactos do desenvolvimento urbano nas águas subterrâneas de Natal -RN. PhD thesis, Inst. Geociíncias, Universidade São Paulo, 196 p.

Rebouças, A.C., 1967. As águas subterrâneas do Nordeste- estimativas preliminares. Serie Hidrogeologia (SUDENE/Brasil) No 1: 120 p, Recife.

Rebouças, A.C., 1973. Le problème de l'eau dans la zone semi-aride du Brèsil: Evaluation des ressources, orientation pour la mise en valeur. $\mathrm{PhD}$ thesis. Universitè Louis Pasteur de Strasbourg- France, 291p.

Rebouças, A.C. 1976. Recursos hídricos subterrâneos da bacia do Paraná Análise de Prè-viabilidade. Reader Professor thesis, Inst. GeociênciasUniversidade de São Paulo. 143 p.

Rebouças, A.C. 1988. Groundwater in Brazil. Episodes, vol. 11, N 3 p 209219.

Rebouças, A.C., 1991. Desarrollo y tendencias de la hidrogeologia en America Latina. in Curso Internacional de Hidrologia Subterránea - Hidrogeologia, Estado Actual y Perspectivas - Anguita, Aparicio, Candela, Zurbano (eds), p 429-453, Barcelona.

Rebouças, A.C. Rincomini, C. Ellert. N., Duarte. U., Mellito, K.M., Senf, L. A. Souza, J.C.S., 1994. Diagnóstico hidrogeológico da RMSP: uso e proteção. Anais Cong. Bras. Águas Subterrâneas - ABAS, p.93-103. Recife.

Rebouças, A.C., 1994b. Sistema aquífero Botucatu no Brasil. Anais $8^{\circ}$ Cong. Bras. Águas Subterrâneas - ABAS, p. 500-509. Recife.

Tancredi, A.C. F.N.S., 1996. Recursos Hídricos Subterrâneos de SantarèmFundamentos para Uso e Proteção. Ph.D. thesis, Centro Geociências, Universidade Federal do Pará. 153 p.

WRI - World Resources Institute, 1991. Freshwater, Tab. 22.1 Freshwater resources and withdrawal. p 330, Oxford.

Aldo da C. Rebouças is Full Professor at the University of São Paulo; twice former President of the Brazilian Association for Groundwater - ABAS, 1985-86, 1993-94; twice President of the Latin American Groundwater Association for the Development - ALHSUD, 1991-94, 1995-98. Certified and Registered Professional Hydrogeologist of the American Institute of Hydrology, his work covers all aspects of hydrogeology from regional studies to management, economics and protection.

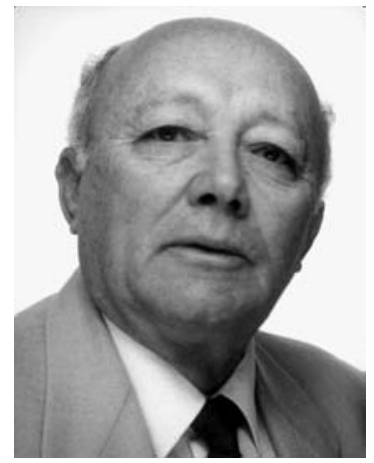

